\title{
A Specific Approach for Estimating Traffic-Induced Urban Pollution
}

\author{
Sadoon Ayed ${ }^{1}$, Mladen Tomić ${ }^{*}$, Predrag Živković \\ 'Department of Mechanical Engineering, University of Technology, Baghdad, Iraq, \\ Al-Sinaa Street, P.O. Box 35010, Baghdad, Iraq \\ ${ }^{2}$ College of Applied Technical Sciences, Niš, Serbia, Aleksandra Medvedeva 20, Niš, Serbia \\ ${ }^{3}$ Faculty of Mechanical Engineering, University of Niš, Aleksandra Medvedeva 14, Niš, Serbia
}

Received: June 5, 2015

Accepted: July 6, 2015

\begin{abstract}
Most air pollution originates from combustion processes, so it is important to make quantitative as well as qualitative analysis, as the sources of pollution can be stochastic - especially for road traffic. The point of our study is to better determine road traffic as one of the largest pollution sources in the city of Niš, Serbia. The research was conducted at several locations in the city that represent all of the main roads across the city. Parameters considered in the study were traffic frequency, vehicle type, annual vehicle mileage in the city, and average vehicle velocity. Besides these parameters, roadside $\mathrm{CO}_{2}$ concentration was measured for evaluation. These data were used as the input for the COPERT methodology of air pollutant emissions calculation from road transport. On the basis of these data, annual $\mathrm{CO}_{2}$ emissions and major pollutants were calculated, as well as the specific average emissions on roads. According to this, a classification of roads in respect to their specific average emissivity is given at the end of this paper.
\end{abstract}

Keywords: COPERT, $\mathrm{CO}_{2}$ emissions, pollutant emissions, air pollution, road traffic

\section{Introduction}

The impact of pollutants as a consequence of a traffic activity $\left(\mathrm{CO}, \mathrm{NO}_{\mathrm{x}}, \mathrm{CO}_{2}, \mathrm{SO}_{\mathrm{x}}\right.$, VOC) has been well documented [1-3]. Recently, since recognizing the problem of global warming caused by GHG emissions, more attention has been focused on $\mathrm{CO}_{2}$ emissions. Vehicles represent one of the greatest emitters of all pollutants, as well as carbon dioxide. As estimated, in the overall balance of $\mathrm{CO}_{2}$ vehicles contribute $10 \%$, and in Europe $20 \%$ of anthropogenic emissions [1]. Countries with rapid urbanization, such as India and China, are becoming increasingly dependent on automobile transport, which has become a major air pollutant in urban areas [4-6]. As has been presented by Živković et al., in the city of Niš this percentage is even higher [2]. Although measuring pollutant concentrations themselves is

*e-mail: mladen.tomic@vtsnis.edu.rs not difficult, a closer determination of traffic sources is very complicated considering their stochastic nature [5]. For this reason, different methods for modelling emissions from traffic were suggested. Such estimates are of great importance for more efficient management of air quality.

Emissions from traffic depend on many parameters: vehicle type, engine displacement, vehicle age, fuel type, cruising speed, etc. Examining the emissions of $\mathrm{CO}_{2}$ and pollutants during the study, the authors have chosen a "macro" or "top-bottom" approach to determine emissions from a single vehicle, based on obtained emissions data. Such data, when they are sufficiently determined, can be used for building a national inventory of emissions [7-9]. In recent years there have been significant efforts to determine emissions in the function of engine type, engine size, and the speed at which the vehicle is moving [8-11].

For this purpose various models for prediction of gaseous emissions were developed $[1,7,12,13]$. The COP- 
ERT computer program developed by Ntziachristos and Samaras was used for this study, which utilizes the macroscopic approach [14]. Emission assessment was done on the basis of data measured at all of the major intersections in the city, as well as from the data obtained from the Republic of Serbia Ministry of Interior Affairs (MUP) in Niš.

\section{Methodology}

Traffic monitoring was done on the main crossroads in the city. Select locations are main street intersections, or characteristic locations on main streets (Fig. 1).

Quantification of traffic intensity was done by counting vehicles that pass through the crossroads, where logging is performed every five min for a period from 5 a.m. to 1 a.m. the next day. This period was chosen as the period when public transport is active, and in the period between 1 a.m. and 5 a.m. traffic in negligible. During counting the vehicles were divided into two categories: passenger cars, and buses and trucks. The category of passenger cars implies scooters, motorcycles, cars, and pickups. As the measurements were done in late autumn, the number of scooters and motorcycles was negligible in comparison to other types of vehicles. During the traffic monitoring, $\mathrm{CO}_{2}$ concentration measurements were performed in order to link the traffic emissions and measured $\mathrm{CO}_{2}$ concentrations.

The vehicle fleet data were imported into the COPERT software package, from which overall traffic emissions were calculated. Average emission output of $\mathrm{CO}_{2}$ and pollutants per vehicle and $\mathrm{km}$ was obtained. The results were used for determining traffic-induced emissions. In order to establish the accuracy of traffic frequency, the crossroads at Location I was monitored during workdays in order to determine measured data statistical stability.

\section{Emission and Emission Factor Calculation}

The fleet composition data used in this paper were obtained from MUP. Based on these data, it was noticed that passenger cars occupy by far the largest share of the fleet. Vehicles with petrol engines are the most common, making almost $2 / 3$ of the fleet, and the average age of vehicles is about 14 years. The emmision values are calculated using the COPERT methodology $[12,14]$. Basically, COPERT was used as a tool for assessing emissions from traffic at the national level. COPERT operation is based on the analysis of large amounts of data from several European vehicle testing facilities. This is a very reliable methodology, since the actual high-level agreement of data obtained [13]. As constant vehicle velocity was adopted, the emission factor for substance $i$ in the specific vehicle category could be calculated as $[13,15]$ :

$$
E F_{i}=b v^{2}+a v+k
$$

Equation (1), from which one calculates the emission factor, is generally approximated by a second-degree polynomial function of average vehicle velocity, or a graph $[1,9,10,13,14]$. Nejadkoorki et al. suggest more complicated formulas for emission calculation as a function of average velocity [1]:

$$
E F_{i}=k+a v+b v^{2}+c v^{3}+\frac{d}{v}+\frac{e}{v^{2}}+\frac{f}{v^{3}}
$$

In eqs. (1) and (2) $k, a, b, c, d, e$, and $f$ are constants.

Some authors obtain the emission factor as a function of acceleration as well as velocity $[9,11,16-18]$. Although $E F_{i}$ is not a constant, it is assumed that for an average vehicle velocity, it is approximately a constant [14].

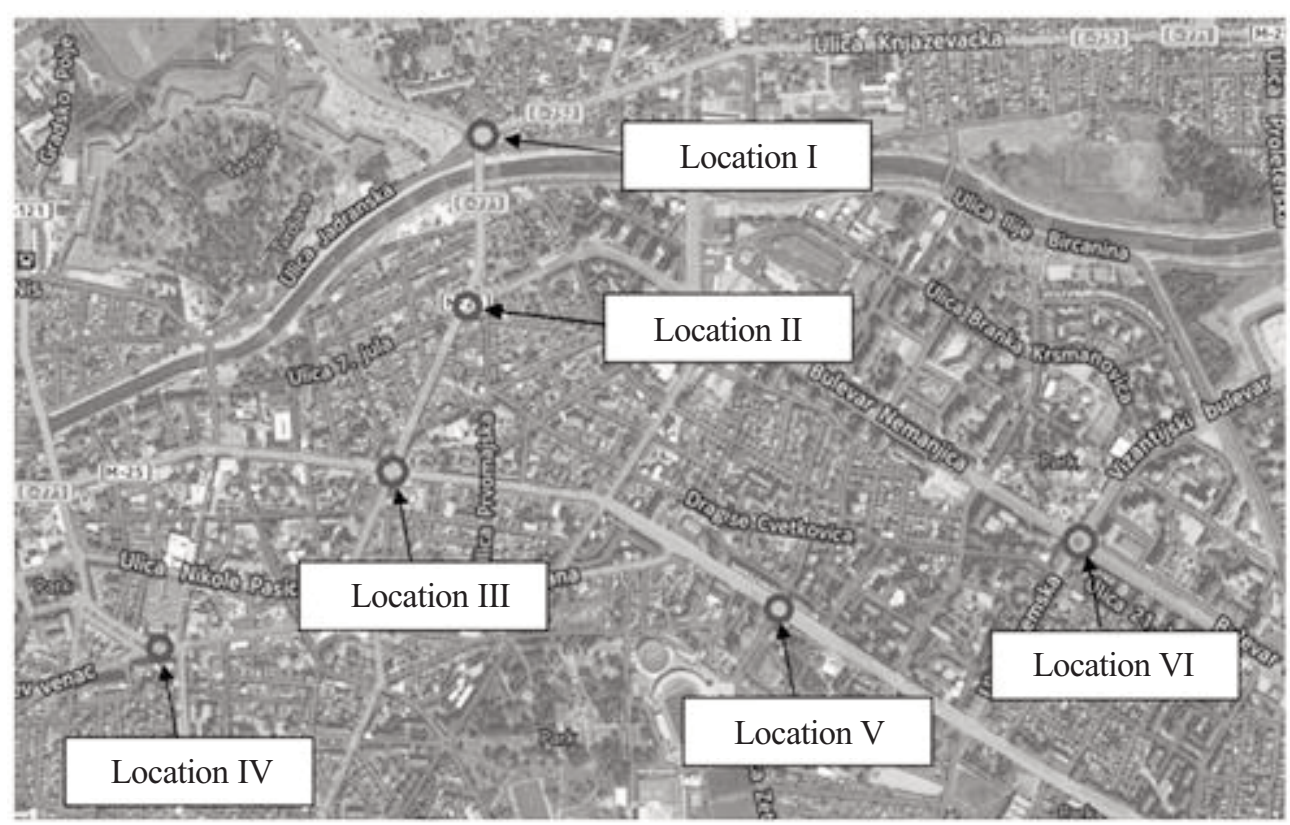

Fig. 1. Measuring locations in the city of Niš. 
Table 1. Personal vehicle fleet composition.

\begin{tabular}{|c|c|c|c|c|c|c|c|}
\hline & & \multicolumn{3}{|c|}{ Gasoline } & LPG & \multicolumn{2}{|c|}{ Diesel } \\
\hline & & $<1.4$ & $1.4-2$ & $>2$ & - & $<2$ & $>2$ \\
\hline PRE ECE & \multirow{5}{*}{ Conventional } & $0.55 \%$ & $0.32 \%$ & $0.03 \%$ & \multirow{5}{*}{$3.54 \%$} & \multirow{5}{*}{$6.30 \%$} & \multirow{5}{*}{$0.22 \%$} \\
\hline ECE $15 / 00-01$ & & $1.55 \%$ & $0.89 \%$ & $0.08 \%$ & & & \\
\hline ECE $15 / 02$ & & $0.90 \%$ & $0.52 \%$ & $0.05 \%$ & & & \\
\hline ECE $15 / 03$ & & $2.92 \%$ & $1.67 \%$ & $0.16 \%$ & & & \\
\hline ECE $15 / 04$ & & $8.17 \%$ & $4.69 \%$ & $0.45 \%$ & & & \\
\hline \multicolumn{2}{|c|}{ PC Euro 1-91/441/EEC } & $2.72 \%$ & $1.56 \%$ & $0.15 \%$ & $0.68 \%$ & $1.22 \%$ & $0.04 \%$ \\
\hline \multicolumn{2}{|c|}{ PC Euro 2-94/12/EEC } & $2.14 \%$ & $1.23 \%$ & $0.12 \%$ & $0.54 \%$ & $0.96 \%$ & $0.03 \%$ \\
\hline \multicolumn{2}{|c|}{ PC Euro 3-98/69/EC Stage2000 } & $3.18 \%$ & $1.82 \%$ & $0.17 \%$ & $0.80 \%$ & $1.42 \%$ & $0.05 \%$ \\
\hline \multicolumn{2}{|c|}{ PC Euro 4-98/69/EC Stage2005 } & $5.86 \%$ & $3.36 \%$ & $0.32 \%$ & $1.47 \%$ & $2.62 \%$ & $0.09 \%$ \\
\hline \multicolumn{2}{|c|}{ PC Euro 5-EC 715/2007 } & $7.49 \%$ & $4.30 \%$ & $0.41 \%$ & $18.78 \%$ & $3.35 \%$ & $0.12 \%$ \\
\hline
\end{tabular}

The relationship between traffic intensity and partial $\mathrm{CO}_{2}$ and $\mathrm{CO}_{2}$ emissions is presented in Fig. 2. According to Fig. 2, the $\mathrm{CO}_{2}$ concentration is over 300 ppm higher than normal concentration in the atmosphere. From this amount approximately $150 \mathrm{ppm}$ originates from traffic. Thus it could be concluded that at the observed locations traffic contributes with almost $20 \%$ to the $\mathrm{CO}_{2}$, which correspondes to other data [1].

The annual $A M_{i}$ emissions of the $i^{\text {th }}$ supstance by a vehicle in the $j^{\text {th }}$ category is equal to:

$$
A M_{i}=\sum_{j} E F_{i, j} \operatorname{num}_{j} L_{j}
$$

...where $\operatorname{num}_{j}$ is the number of vehicles in the $j^{\text {th }}$ category, $E F_{i, j}$ is the emission factor for $i^{\text {th }}$ supstance in the $j^{\text {th }}$ category, and $L_{j}$ is average annual mileage for the vehicle in the $j^{\text {th }}$ category.

Simmilary, the annual roadside emission $R M_{i}$ is equal to:

$$
R M_{i}=31.563 \cdot 10^{6} \sum_{j} E F_{i, j} f_{j} S_{j}
$$

...where $f$ is the average daily frequency of vehicles $\left[\mathrm{s}^{-1}\right]$ in the jth category, $S_{j}$ is the length of observed section, and $31.563 \cdot 10^{6}$ is the number of seconds in a year.

On the basis of eq. (3) it is possible to estimate error as:

$$
\begin{gathered}
\delta A M_{i}=\delta E F_{i, j} \operatorname{num}_{j} L_{j}+E F_{i, j} \delta n u m_{j} L_{j}+ \\
+E F_{i, j} \text { num }_{j} \delta L_{j}
\end{gathered}
$$

...and, similary, on the basis of eq. (4) and error estimations:

$$
\delta R M_{i}=\delta E F_{i, j} f_{j} S_{j}+E F_{i, j} \delta f_{j} S_{j}
$$

\section{Fleet Composition}

As has been stated earlier, MUP data were used for analysis. Vehicles were divided into the following categories: personal vehicles, buses, trucks, and motorcycles.

\section{Personal Vehicles}

Passenger cars by far represent most of the fleet at 58,049 , or $91.12 \%$ of the fleet. Before inputting the data into the COPERT, statistical averaging was carried out while processing the data obtained from MUP (Table 1), in order to adjust them for use in COPERT. For the average mileage per year in the city, an amount of 3,500 km annualy was adopted, assuming that the average urban drive amounts to $10 \mathrm{~km}$ daily [15] (the amount was adopted on the basis of the author's expirience and direct odometer reading). According to the Serbian Environmental Protection Agency data and data presented in Table 1, it could be calculated that the average personal vehicle in the city of Niš is driven approximately $13,400 \mathrm{~km}$ per year,

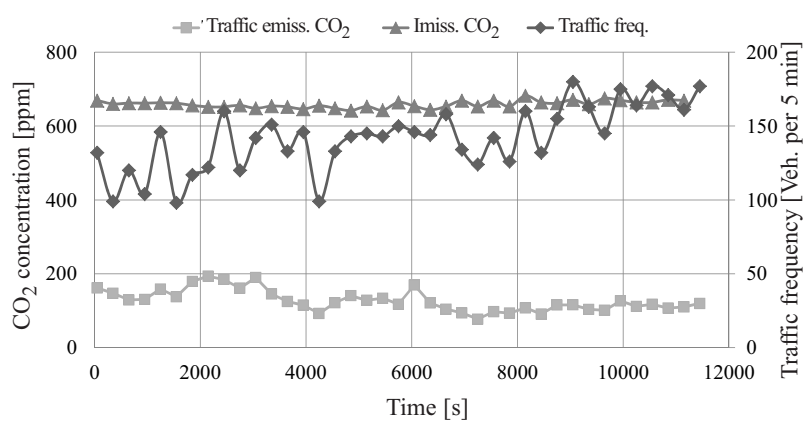

Fig. 2. Comparison of traffic frequency, measured $\mathrm{CO}_{2}$ concentrations, and calculated $\mathrm{CO}_{2}$ emissions. 
Table 2. Emission factors for vehicle categories $\left[\mathrm{g} \cdot \mathrm{km}^{-1}\right]$.

\begin{tabular}{|l|c|c|c|}
\hline \multicolumn{1}{|c|}{ Vehicle type } & $\mathrm{CO}_{2}$ & $\mathrm{CO}$ & $\mathrm{NO}_{\mathrm{x}}$ \\
\hline Personal vehicles & 330 & 9.7 & 0.763 \\
\hline Buses & $2,410.8$ & 4.7 & 1.433 \\
\hline Trucks & 500 & 9.4 & 2.514 \\
\hline
\end{tabular}

with a deviation of $7.5 \%$, which was adopted as the value of data uncertainty [19]. The average vehicle velocity and annual mileage were adopted by monitoring the driving habits of Niš citizens.

\section{Buses}

Four-hundred and seventy-seven buses are registered in Niš. However, during the emissions calculation only buses from the public transport company were used in the account. According to the most recently available data, 124 buses were engaged in the city of Niš public transport, and they were driven $8,609,250 \mathrm{~km}$ annually [20]. This makes public transport buses far more influential in comparison with other busses that travel through the city.

\section{Trucks}

During traffic frequency counting, light trucks were counted among passenger cars. The authors have adopted as a boundary between light and heavy trucks an engine displacement of $2,000 \mathrm{~cm}^{3}$. All transport vehicles with engines larger than $2,000 \mathrm{~cm}^{3}$ were categorized as heavy trucks. According to this, there are 2,286 trucks in the city. For annual mileage $2,000 \mathrm{~km}$ was adopted for city territory, with an assumed uncertainty of $17 \%$.

\section{Motorcycles}

During the considered period the number of motorcycles on the streets was negligible.

\section{Emission Factors}

COPERT analysis has shown that average personal vehicle emissions are consistent with other data presented in Table 2 [21-25]. Due to specific features of the fleet in Niš, compared with Western European and U.S. fleets (average age of the fleet), the advantage has been given to the locally defined emission coefficient.

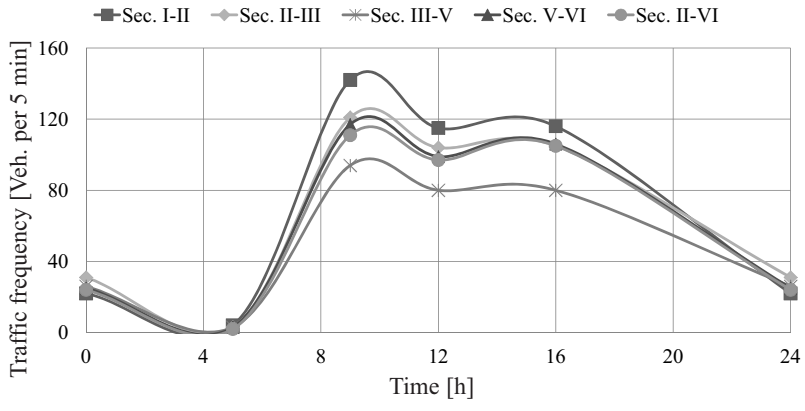

Fig. 3. Daily variation of personal vehicle traffic on street sections.

\section{Model Validation}

The results of traffic frequency monitoring at Location I are shown in Table 3 with daily variations. It could be concluded from the results in the table that the total number of passenger vehicles during a workday does not vary more than $3.46 \%$, compared to the average. Also, in the graphics in Fig. 3 one can see the similarity of curves representing the frequency of traffic throughout the day. On the graph in Fig. 3 two peaks could be noted: in the period 8-9 a.m., and 3-4 p.m. Those periods correspond to the daily morning and evening rush-hours. For the buses and truck traffic, the biggest difference in total traffic frequency, in comparison with average traffic frequency, is higher and amounts to $8.13 \%$, which is in the acceptable limits (Table 3).

On the basis of traffic deviation data, emission deviation data, and eq. (4), it is possible to calculate emission deviation. Deviations have been presented in the table for the observed sections, and for total annual emissions. The analysis of the method conducted by Sturm et al. has shown that, depending on the method, deviations can vary up to $36 \%$ [26]. The main reason for high values of uncertainty is the uncertainty of emissions data, but also the uncertainty of average mileage traveled through the city.

The error of the emission factors $\varepsilon_{i, j}$ have been estimated in respect to average results for emission factors:

$$
\varepsilon_{i, j}=\left|\overline{E F}_{i, j}-E F_{i, j}\right|
$$

...where $\overline{E F}_{i, j}$ represents the average emission factor (Table 2). The results are presented in Table 4.

Table 3. Traffic fluctuations at Location I.

\begin{tabular}{|l|c|c|c|c|c|c|}
\hline \multicolumn{1}{|c|}{ Day } & I & II & III & IV & Average & $\sigma$ \\
\hline No. personal vehicles & 38,721 & 37,182 & 40,428 & 38,408 & 38,685 & $1,338(3.45 \%)$ \\
\hline No. buses and trucks & 2,839 & 2,951 & 3,421 & 3,380 & 3,148 & $256(8.13 \%)$ \\
\hline
\end{tabular}


Table 4. Error estimation for emission factors $\left[\mathrm{g} \cdot \mathrm{km}^{-1}\right]$.

\begin{tabular}{|l|c|c|c|}
\hline \multicolumn{1}{|c|}{ Authors } & $\mathrm{CO}_{2}$ & $\mathrm{CO}$ & $\mathrm{NO}_{\mathrm{x}}$ \\
\hline Current research & 330 & 9.7 & 0.763 \\
\hline Joumard et al. [22] & 225 & 2.5 & - \\
\hline Samaras [21] & 300 & 5 & - \\
\hline EPA [24] & 368 & 5.84 & 0.693 \\
\hline Boričić [23] & - & 15.98 & - \\
\hline Leinert [25] & - & - & 0.660 \\
\hline Average & 306 & 7.80 & 0.705 \\
\hline$\varepsilon_{\max }$ & $7.3 \%$ & $24.3 \%$ & $8.01 \%$ \\
\hline
\end{tabular}

\section{Results and Discusion}

Based on traffic frequency stability data at major intersections, it is possible to determine the approximate number of vehicles on the section between monitoring crossroads (Fig. 3). According to eqs. (3) and (4), it is possible to calculate overall annual emissions for Niš, and the annual emissions for the main roads in the city. The results are presented in Tables 5, 6, and 7 .

Niš has $286.1 \mathrm{~km}$ of streets and local roads. The monitored street sections are $4.4 \mathrm{~km}$ long, which makes $1.5 \%$ of

Table 5. Overal annual emissions.

\begin{tabular}{|l|c|c|c|c|c|}
\hline Vehicle & $\begin{array}{c}\text { No. of } \\
\text { vehicles } \\
\text { mileage } \\
{[\mathrm{km}]}\end{array}$ & $\begin{array}{c}\text { Annual } \\
\mathrm{tCO}_{2} / \mathrm{yr}\end{array}$ & $\mathrm{tCO} / \mathrm{yr}$ & $\mathrm{tNO}_{\mathrm{x}} / \mathrm{yr}$ \\
\hline $\begin{array}{l}\text { Personal } \\
\text { vehicles }\end{array}$ & 58.049 & 3,500 & 67,047 & $1,970.8$ & 155 \\
\hline Buses & 124 & 69,500 & 20,778 & 40.5 & 12.4 \\
\hline Trucks & 2,286 & 2,000 & 2,286 & 43 & 11.5 \\
\hline Sum & 60,459 & - & 90,111 & $2,054.3$ & 178.8 \\
\hline$\varepsilon_{\max }$ & - & - & $22.0 \%$ & $35.5 \%$ & $20.0 \%$ \\
\hline
\end{tabular}

Table 6. Personal vehicle emissions estimation on observed street sections.

\begin{tabular}{|c|c|c|c|c|}
\hline Section & $\begin{array}{c}\text { Lenght } \\
{[\mathrm{km}]}\end{array}$ & $\mathrm{tCO}_{2} / \mathrm{yr}$ & $\mathrm{tCO} / \mathrm{yr}$ & $\mathrm{tNO}_{\mathrm{x}} / \mathrm{yr}$ \\
\hline II-VI & 1.63 & $3,681.0$ & 108.2 & 8.5 \\
\hline II-III & 0.38 & 858.2 & 25.2 & 2.0 \\
\hline V-VI & 1 & $2,258.3$ & 66.4 & 5.2 \\
\hline III-V & 0.95 & $2,526.6$ & 74.3 & 5.8 \\
\hline I-II & 0.39 & 710.3 & 20.9 & 1.6 \\
\hline Sum & - & $10,034.3$ & 295.0 & 23.2 \\
\hline$\varepsilon$ & - & $10.7 \%$ & $27.7 \%$ & $11.5 \%$ \\
\hline
\end{tabular}

Table 7. Bus and truck emission estimations on observed street sections.

\begin{tabular}{|c|c|c|c|c|}
\hline Section & $\begin{array}{c}\text { Lenght } \\
{[\mathrm{km}]}\end{array}$ & $\mathrm{tCO}_{2} / \mathrm{yr}$ & $\mathrm{tCO} / \mathrm{yr}$ & $\mathrm{tNO}_{\mathrm{x}} / \mathrm{yr}$ \\
\hline II-VI & 1.63 & $1,461.2$ & 9.7 & 2.7 \\
\hline II-III & 0.38 & 393.2 & 2.6 & 0.7 \\
\hline V-VI & 1 & 247.1 & 1.64 & 0.46 \\
\hline III-V & 0.95 & $1,086.3$ & 0.5 & 0.14 \\
\hline I-II & 0.39 & 403.6 & 0.14 & 0.04 \\
\hline Sum & - & $3,591.4$ & 14.5 & 4.04 \\
\hline$\varepsilon$ & - & $15.4 \%$ & $32.3 \%$ & $16.1 \%$ \\
\hline
\end{tabular}

Table 8. Average emission factors for streets in Niš $\left[\mathrm{g} \cdot \mathrm{km}^{-1} \cdot \mathrm{s}^{-1}\right]$.

\begin{tabular}{|l|c|c|c|}
\hline & $\mathrm{CO}_{2}$ & $\mathrm{CO}$ & $\mathrm{NO}_{\mathrm{x}}$ \\
\hline I category & 98.2 & 2.2 & 0.2 \\
\hline II category & 9.3 & 0.21 & 0.02 \\
\hline
\end{tabular}

overall streets in the city [27]. The traffic in these street sections contributes $15.1 \%$ to the total annual emissions in the city. Results for each section are presented in Table 6 for personal vehicle subcategory, and in Table 7 for buses and trucks. Based on this fact, it is possible to divide streets in the city into two categories (Table 8 ). The first category occupies monitored street sections (which represents the main roads), and the second category represents side roads, whose specific average emission is at least 10 times lower than the emissions of the fist category.

\section{Conclusions}

This paper presents a method for determining street emissions. During the study, six major crossroads in the city were monitored. Monitoring of the crossroads has enabled the determination of traffic intensity on straight sections between the crossroads. In order to calculate specific emissions of the city fleet, the fleet composition data were obtained from MUP. According to this data, specific vehicle emissions and total annual emissions were calculated using the COPERT methodology.

Analysis showed that on observed sections, the specific emissions are 11 times higher compared to the rest of the streets in the city. Based on this fact, streets were divided into two categories: main streets and side streets. At the end of the paper an error analysis was given. Although high, the error is still at reasonable value. There is still a need for further research, however, since there are still many gaps in the emissions data. Closer determination of input data would additionally increase the quality of results, and therefore output data. 


\section{Acknowledgements}

This paper is part of research done within project III 42008 supported by the Ministry of Education, Science, and Technological Development of the Republic of Serbia.

\section{References}

1. NEJADKOORKI F., NICHOLSON K., LAKE I., DAVIES T. An approach for modeling $\mathrm{CO}_{2}$ emission from road traffic in urban areas. Sci. Total Environ. 406, (1-2), 269, 2008.

2. ŽIVKOVIĆ P., ILIĆ G., TOMIĆ M., VUKIĆ M., STEVANOVIĆ Ž., STEVANOVIĆ Ž., OGRIZOVIĆ M. Air pollution estimation in the city of Niš. International Conference Power Plants 2010, October, 2010 [In Serbian].

3. NIKOLAOUA K., TSARSITALIDISB H., PAPADAKISC $\mathrm{N}$. Traffic and air pollution temporal evolution in the city of Serres, Greece. Journal of Environmental Protection and Ecology. 10, (2), 320, 2009.

4. NESAMANI K. S. Estimation of automobile emissions and control strategies in India. Sci. Total Environ. 408, (8), 1800, 2010.

5. DU Y., GENG Y., SUN L. Simulation model based on Monte Carlo method for traffic assignment in local area road network. Front. Archit. Civ. Eng. China. 3, (2), 195, 2009.

6. STURM P., ALMBAUER R., SUDY C., PUCHER K. Application of computational methods for the determination of traffic emissions. Air Waste Manage Assoc. 47, (11), 1204, 1997.

7. MACHADO A., GARCÍA N., HUERTAS J., GARCÍA C., FERRER N., LEÓN R., VERÓNICA MACHADO M. Air emissions inventory of the public transport in maracaibo municipality. Part I: Passenger car. Revista Técnica de la Facultad de Ingeniería Universidad del Zulia. 27, (3), 202, 2004 [In Spanish].

8. ANDRE M., HAMMARSTROM U. Driving speeds in Europe for pollutant emissions estimation. Transport. Res. D-Tr. E. 5, (5), 321, 2000.

9. JOUMARD R., JOST P., HICKMAN J., HASSEL D. Hot passenger car emission modeling as a function of instantaneous speed and acceleration. Sci. Total Environ. 169, (13), 321, 1995.

10. WASHBURN S., SEET J., MANNERING F. Statistical modelling of vehicle emissions from inspection/maintenance testing data: an exploratory analysis. Transport. Res. D-Tr. E. 6, (1), 21, 2001.

11. NESAMANIA K. S., CHU L., MCNALLY M. G., JAYAKRISHNAN R. Estimation of vehicular emissions by capturing traffic variations. Atmos. Environ. 41, (14), 2996, 2007.

12. DE HAAN P., KELLER M. An Emission factors for passenger cars: application of instantaneous emission modelling. Atmos. Environ. 34, (27), 4629, 2000.

13. KASSOMENOS P., KARAKITSIOS S., PAPALOUKAS C. Estimation of daily traffic emissions in a South-European urban agglomeration during a workday. Evaluation of several “what if" scenarios. Scie. Total Environ. 370, (2-3), 480, 2006.
14. NTZIACHRISTOS L., SAMARAS Z. COPERT 3-Computer Programme to calculate Emissions from Road Transport, Methodology and emission factors. Technical report No 49. European Environment Agency Copenhagen, 2000.

15. TOMIĆ M., ŽIVKOVIĆ P., ILIĆ G., VUKIĆ M., MILISAVLJEVIĆ J., ĐEKIĆ P. A method for defining streets as sources of $\mathrm{CO}_{2}$ emission and their classification in the city of Niš. $15^{\text {th }}$ International Symposium on Thermal Science and Engineering of Serbia - SIMTERM 2011, October 2011.

16. ANDRE M., RAPONE M. Analysis and modelling of the pollutant emissions from European cars regarding the driving characteristics and test cycles. Atmos. Environ. 43, (5), 986, 2009.

17. MARMUR A., MAMANE Y. Comparison and evaluation of several mobile source and linesource models in Israel. Transport. Res. D-Tr. E. 8, (4), 249, 2003.

18. WINTHER, M. Petrol passenger car emissions calculated with different mission models. Sci. Total Environ. 224, (13), 149, 1998.

19. SERBIAN ENVIRONMENTAL PROTECTION AGENCY: Determination of the amounts of emission of gaseous pollutants originating from road transport applying the COPERT IV model by European Environmental Agency. http: //www. sepa.gov.rs/download/COPERT.pdf

20. DIRECTORATE FOR PUBLIC TRANSPORT IN NIŠ: http://www.jgpnis.rs/index.php/linije/2010-04-27-08-4417.html (accesed on 8.2.2015) [In Serbian].

21. SAMARAS Z., NTZIACHRISTOS L. Average hot emission factors for passenger cars and light duty trucks. In the Project: Methodologies for estimating air pollutant emissions from transport (MEET) \pm , LATReport 9811. Laboratory of Applied Thermodynamics, Report 7, Aristotle Universitet, Thessaloniki, 1998.

22. JOUMARD R., ANDRE M., VIDON R., TASSEL P., PRUVOST C. Influence du cycle de conduite sur les emissions unitaires de pollutants des voitures particulieres. INRETS Report, No. LTE 9902, Bron, 1999 [In French].

23. BORIČIĆ A., TOMIĆ M. An estimation of traffic related carbon monoxide emission in the city of Niš. Online Journal of Applied Knowledge Management. 2, (3), 65, 2014.

24. EPA, Average Annual Emissions and Fuel Consumption for Gasoline-Fueled Passenger Cars and Light Trucks. http://www.epa.gov/otaq/consumer.htm\#pollutant (accesed on 8.2.2015)

25. LEINERT S., HYDE B., COTTER E. Relative NOx emissions from road transport, for different vehicle types and technologies. Irish Transport Research Network ITRN2011. Cork, Ireland, August, 2011.

26. STURM P. J., PUCHER K., SUDY C., ALMBAUER R. A. Determination of traffic emission - intercomparison of different calculation methods. Sci. Total Environ. 189-190, 187, 1996.

27. FILIPOVIĆ S., GAVRILOVIĆ S., ŽIVANOVIĆ P., MILOVANOVIĆ B. Study of the Public Transport in Niš. Technical Report. Faculty of Transport and Traffic Engineering in Belgrade, 2007 [In Serbian]. 